Contribution No. 1239. Work was performed in the Ames Laboratory of the U.S. Atomic Energy Commission.

\title{
SEPARATION AND SPECTROPHOTOMETRIC DETERMINATION OF RARE EARTHS
}

\section{HIROSHI ONISHI AND CHARLES V. BANKS}

Institute for Atomic Research and Department of Chemistry, Iowa State University, Ames, Iowa

\section{(Received}

Summary - At the present time arsenazo appears to be widely used for the spectrophotometric determination of rare earths. Unfortunately, the method is not selective. The separation of rare earths and yttrium from interfering elements has been studied, and the fol:owing method has been proposed. Rare earths are precipitated as fluorides using calcium fluoride as the carrier. Thorium and zirconium are removed by extraction with thenoyltrifluoroacetone (TTA) in xylene at pH 1.3. Small amounts of residual aluminum, iron, etc. are removed by extraction with 8-quinolinolchloroforn at $\mathrm{pH}$ 4.5. Rare earths are separated from calcium by TTA extraction at the same $\mathrm{pH}$, and they are then back-extracted into $1 \mathbf{M}$ nitric acid. After evaporation of the solution, the rare earths are determined spectrophotometrically with arsenazo.

\section{INTRODUCTION}

A though arsenazo is not particialariy selective, it appears to be widely used for the spectrophotometric determination of the rare earths and yttrium at the present time. New reagents such as bromopyrogall red, ${ }^{1}$ salicylfiuorone, ${ }^{2}$ and arsenazo III $^{3}$ do not seem to be definitely more selective than arsenazo. Yttrium may 
be determined spectrophotometrically with pyrocatechol violet after a preliminary separation from 1ron, uranium, zirconium, thorium, and molybdenum with tri-n-octylphosphine oxide. ${ }^{4}$ However, the behavior of rare earths and scandium remains to be established. Thus a generally applicable method is needed for the separation of rare earths.

Arsenazo has been used for the determination of rare earths in uranium, ${ }^{5,6}$ cast steels, ${ }^{7}$ ores and rocks, ${ }^{8}$ and soils. ${ }^{9}$ A method was proposed for the successive determination of rare earths and thorium with arsenazo. 10

For the purpose of extending the applicability of the spectrophotometric determination of rare earths with arsenazo, the separation of these elements from interfering elements have been studied.

\section{AFPARATUS}

Absorbance measurements were made with a Beckman Model DU spectrophotometer, using 1-cm. cells. A Beckman Model G pH meter was used for pH measurements. For centrifugal separations, an Internationa clinical centrifuge with 50-ml. Lusteroid tubes was used. A shaking machine, Burrell shaker, with a time switch was used for extractions.

\section{REAGENTS}

Calcium nitrate, $10 \mathrm{mg} \cdot \mathrm{Ca} / \mathrm{ml}: 5.89 \mathrm{~g}$. of $\mathrm{Ca}\left(\mathrm{NO}_{3}\right)_{2} \cdot 4 \mathrm{H}_{2} \mathrm{O}$ in $100 \mathrm{ml}$. of water. 
Thenoyltrifluoroacetone (TTA), $0.5 \mathrm{M}: 45 \mathrm{~g}$. in $400 \mathrm{ml}$. of xylene.

8-quinolinol: $5.0 \mathrm{~g}$. of 8-yuinolinol was dissolved in $10 \mathrm{mi}$. of glacial acetic acid and the solution was diluted to $100 \mathrm{ml}$. w1th water.

Ammonium acetate, $3.5 \mathrm{M}: 135 \mathrm{~g}$. in $500 \mathrm{ml}$. of water.

Acetic acid-sodium acetate: $0.1 \underline{\mathrm{M}}$ acetic acid and $0.1 \underline{\mathrm{M}}$ sodium acetate $\left(13.6 \mathrm{~g}\right.$. of $\mathrm{NaC}_{2} \mathrm{H}_{3} \mathrm{O}_{2} \cdot 3 \mathrm{H}_{2} \mathrm{O}$ in 1 l. of water) were mixed so that the $\mathrm{pH}$ of the mixture became $4.6 \pm 0.1$. Instead of sodium acetate, ammonium acetate may be used.

Arsenazo: $0.10 \mathrm{~g}$. in $100 \mathrm{ml}$. of water.

Triethanolamine buffer: $400 \mathrm{ml}$. of $15 \%(\mathrm{w} / \mathrm{v})$ triethanolamine solution, $330 \mathrm{ml}$. of $1 \mathrm{M}$ nitric acid, and $70 \mathrm{ml}$. of water were mixed. The $\mathrm{pH}$ was adjusted to $7.2 \pm 0.1$ with dilute nitric acid or ammonium hydroxide.

Standard cerium solution, $1.00 \mathrm{mg}$. Ce/ml.: $10 \mathrm{ml}$. of water, $10 \mathrm{ml}$. of $70 \%$ perchloric acid, and $1 \mathrm{ml}$. of $30 \%$ hydrogen peroxide were added to $0.1228 \mathrm{~g}$. of $\mathrm{CeO}_{2}$ that was previously ignited. On heating, the oxide dissolved and the resulting solution was evaporated to dryness. Ten $\mathrm{ml}$. of $1 \mathrm{M}$ nitric acid and $1 \mathrm{ml}$. of $30 \%$ hydrogen peroxide were added, and the solution was boiled for 5 minutes. After cooling, the solution was diluted to exactly $100 \mathrm{ml}$. with water.

Standard solutions of gadolinium ( $1 \mathrm{mg} . \mathrm{Gd} / \mathrm{ml}$.) and yttrium (1 mg. Y/ml.): The oxides were ignited and weighed. They were dissolved in a slight excess of nitric acid, and the solutions were diluted to appropriate volumes with water. 


\section{EXPERIMENTAL WORK}

\section{Fluoride precipitation. Transfer the sample solution} $(0.5 \mathrm{M}$ in nitric acid and containing 20 to $100 \mu \mathrm{g}$. of rareearth metals or 10 to $60 \mu \mathrm{g}$. of yttrium in a volume of approximately $50 \mathrm{ml}$.) tc a polyethylene beaker and add $1.0 \mathrm{ml}$. of calcium nitrate solution and $10 \mathrm{ml}$. of $48 \%$ hydrofluoric acid. Set the solution aside overnight.

Transfer the fluorides to a 50-ml. Lusteroid centrifuge tube and separate at the full speed of the centrifuge for about 5 minutes. Carefully pour off the supernatant liquid. Wash the precipitate 3 times with 10-ml. portions of 1:5 hydrofluoric acid. Transfer the precipitate to a platinum dish with a minimum amount of $2 \underline{M}$ nitric acid. Add $2 \mathrm{mi}$. of $70 \%$ perchloric acid and evaporate the solution to near dryness. (Note: If iron is present, it is important that the solution not be evaporated to complete dryness.).

TIA extraction at $\mathrm{pH}$ 1.3. Dissolve the residue in $7.0 \mathrm{ml}$. of $0.1 \mathrm{M}$ nitric acid and transfer the solution to a $60-\mathrm{ml}$. separatory funnel. Wash the dish with $7 \mathrm{ml}$. of water. (If necessary, confirm that the $\mathrm{pH}$ of the solution is $1.3 \pm 0.1$ ). Shake the solution for 5 minutes with $10 \mathrm{ml}$. of TTA solution. When the layers have separated, drain off the aqueous phase into a second separatory funnel. Discard the organic phase. Add $10 \mathrm{ml}$. of TTA solution to the second separatory funnel. Shake the system for 5 minutes and discard the organic phase. Wash the aqueous phase by shaking it for 10 seconds with $10 \mathrm{ml}$. of xylene and discard the organic phase. 
8-Quinolinol extraction. To the aqueous phase add $1.0 \mathrm{ml}$. of 8-quinolinol solution, $1.0 \mathrm{ml}$. of ammonium acetate solution, and $1.0 \mathrm{ml}$. of $0.7 \mathrm{M}$ ammonium hydroxide. If the $\mathrm{pH}$ of the solution is not in the range 4.5 to 4.8 , adjust with dilute nitric acid or ammonium hydroxide. Add $20 \mathrm{ml}$. of chloroform and shake the system for 1 minute. When the layers have separated, drain off and discard the organic phase. Add $0.3 \mathrm{ml}$. of 8-quinolinol solution and $20 \mathrm{ml}$. of chloroform and equilibrate the phases for 1 minute. Discard the organic phase. Wash tne aqueous phase by shaking 1t for 10 seconds with $20 \mathrm{ml}$. of chloroform and discard the organic phase.

ITA extraction at $\mathrm{pH} 4.5$. Shake the aqueous phase for 5 minutes with $15 \mathrm{ml}$. of TTA solution. When the layers have separated, drain off the aqueous phase into a second separatory funnel. Add $15 \mathrm{ml}$. of TTA solution to the second separatory funnel. Shake the system for 5 minutes and discard the aqueous phase. Combine the second extract with the first and wash the extracts by equilibrating them for 10 seconds with $10 \mathrm{ml}$. of acetic acid-sodium acetate solution. Discard the aqueous phase.

Shake the organic phase for 5 minutes with $25 \mathrm{ml}$. of $1 \underline{M}$ nitric acid. Transfer the aqueous phase to another separatory funnel. Discard the organic phase. Shake the aqueous phase for 10 seconds with $10 \mathrm{ml}$. of xylene. Transfer the aqueous phase to a 50-ml. beaker and evaporate to dryness. To the residue add' 1 $\mathrm{ml}$. of $70 \%$ perchloric acid and $1 \mathrm{ml}$. cf concentrated nitric acid. Evaporate the solution to dryness. Wash the sides of the beaker with a minimum amount of water and evaporate the solution to dryness. 
Spectrophotometric determination of rare earths. Dissolve the residue in $1.0 \mathrm{ml}$. of $0.1 \mathrm{M}$ nitric acid. Add $4=$. of water, $\mathrm{mix}$, and add $2.0 \mathrm{ml}$. of arsenazo solution. Add $5.0 \mathrm{ml}$. of triethanolamine buffer solution and $1.0 \mathrm{ml}$. of $0.1 \mathrm{M}$ ammonium hydroxide. Confirm that the pH of the solution is $7.2 \pm 0.1$. Transfer the solution to a $25-\mathrm{ml}$. volumetric flask and dilute to the mark with water. Measure the absorbance of the solution in a $1-\mathrm{cm}$. cell at $580 \mathrm{~m} \mu$, using water (or reagent blank) as the reference.

Construct a calibration curve by taking, for example, 0 , 25,50 , and $75 \mu \mathrm{g}$. of rare-earth metals or $0,20,40$, and $60 \mu \mathrm{g}$. of yttrium and carrying them through the entire procedure using water (or reagent blank) as the reference.

\section{RESULTS AND DISCUSSION}

Interference study. Kuznetsov ${ }^{11}$ has reported that arsenazo forms colored solutions or precipitates with the following lons in neutral media: rare earths, scandium, yttrium, uranium(VI), copper, aluminum, vanadium(IV), thorium, zirconium, gallium, indium, palladium, iron(III), titanium, and chromium(III). Beryllium ${ }^{12}$ also gives a color. Because no quantitative data on interferences in the determination of the rare earths have been published, the absorbances of the solutions ( $\mathrm{pH} 7.2,25 \mathrm{mi}$.) containing metal ions and arsenazo were measured at $580 \mathrm{~m}_{\mu}$. The results are shown in Table I. Gadolinium was chosen to represent rare earths. Previous work ${ }^{10}$ has shown that the absorbance of $20 \mathrm{\mu g}$. Th is nearly the same as that of $16 \mu \mathrm{g}$. Gd. 
ThILE I. COLOR REACTIONS OF METALS WITH ARSENAZO

\begin{tabular}{|c|c|c|c|}
\hline Metal, & $\mathrm{mg}$. & Absorbance & $\begin{array}{l}\text { Gd Equal to } \\
\text { Absorbance, } \mu \mathrm{g} \text {. }\end{array}$ \\
\hline Al(III) & 0.030 & 0.526 & 76 \\
\hline $\mathrm{Cs}(\mathrm{II})$ & 0.10 & 0.012 & 2 \\
\hline $\mathrm{Cd}(\mathrm{II})$ & 0.10 & 0.015 & 2 \\
\hline $\mathrm{Co}(\mathrm{II})$ & 0.10 & 0.087 & 13 \\
\hline $\mathrm{Cr}($ III $)$ & 0.10 & $0.032^{a}$ & 46 \\
\hline$C \cdot($ II $)$ & 0.10 & 0.174 & 25 \\
\hline $\mathrm{Fe}($ III $)$ & 0.10 & 0.369 & 53 \\
\hline $\operatorname{Mg}(I I)$ & 0.10 & 0.041 & 6 \\
\hline $\operatorname{Mn}(I I)$ & 0.10 & 0.095 & 14 \\
\hline Mo(VI) & $0.20^{b}$ & 0.000 & 0 \\
\hline N1 (II) & 0.10 & 0.075 & 10 \\
\hline $\mathrm{Pb}(\mathrm{II})$ & $0.10^{b}$ & 0.007 & 1 \\
\hline $\mathrm{Sc}($ III $)$ & 0.050 & 0.678 & 98 \\
\hline$U(V I)$ & 0.050 & 0.171 & 25 \\
\hline $\ln (I I)$ & 0.050 & 0.050 & 7 \\
\hline $\mathrm{Zr}(\mathrm{IV})$ & 0.10 & 0.563 & 81 \\
\hline
\end{tabular}

a Ausorbance increases with time. Measurement was made 25 minutes after addition of reagents.

b This amount of Mo or $\mathrm{Pb}$ does not interfere with the deternination of $53 \mu \mathrm{\mu g}$. Gd.

\section{Fluoride precipitation. Sandeliti has suggested the use of} calcium salts or strontium saits as a carrier in the precipitation of small amounts of rargeaiths as fluorides or oxalates. Bornong 
and Moriarty ${ }^{7}$ used thorium as a carrier for the precipitation of rare-earth fluorides and oxalates. Becaluse thorium is a more serious interference in the arsenazo method than is calcium, the latter was chosen as a carrien in the present work. The optimal conditions for the fluoride precipitation, as described in the procedure, gave 92 to $94 \%$ recovery of the gadolinium. Calcium was removed by TTA extraction at $\mathrm{pH} 4.5$ prior to the gadolinium determination.

All the recoveries in Tables II to $V$ were calculated by referring to the calibration curve obtained without the separation of gadolinium, cerium, or yttrium. The recoveries from fluoride Arecipitation and TTA extraction are close to those from TTA extraction at $\mathrm{pH}$ 4.5 (Table III) indicating almost complete precipitation of gadolinium as fluoride.

Under the optimum conditions for the precipitation of gadolinium fluoride, 5 and $21 \mathrm{mg}$. of iron(III) gave absorbances corresponding to $25 \mu \mathrm{g}$. and $14 \mu \mathrm{g}$. Gd, respectively. Ten mg. of aluminum gave an absorbance of about 1.8 ; more than $0.1 \mathrm{mg}$. of aluminum was therefore found in the fiuoride precipitate.

8-quinolinol-chlor oform extraction. Since complete removal of iron and aluminum from rare earths was not effected either by fluoride prectpitation or by TTA extractions, 8-quinolinolchluroform extraction was examined. The following method was found to be applicable to at least $1 \mathrm{mg}$. each iron and aluminum.

To a $10-\mathrm{ml}$. aqueous solution, $1.0 \mathrm{ml}$. of $5 \%$-quinolinol in dilute acetic acid, $1.0 \mathrm{ml}$. of $3.5 \mathrm{M}$ ammonium acetate, and 
$3 \mathrm{ml}$. of water were added. The $\mathrm{pH}$ of the solution was 4.8 . Twenty $\mathrm{ml}$. of chloroform was added and the system was shaken for 1 minute. After removal of the organic phase, $0.3 \mathrm{ml}$. of $5 \% 8$-quinolinol solution and $20 \mathrm{ml}$. of chloroform were added and the system was shaken for 1 minute. The organic phase was. removed and the aqueous phase was shaken for 1 minute with $20 \mathrm{ml}$. of chloroform. The aqueous phase was evaporated to dryness. Three $\mathrm{ml}$. of concentrated nitric acid and $1 \mathrm{ml}$. of concentrated hydrochloric acid were added and the solution was again evaporated to dryness. Gadolinium was then determined by the arsenazo method.

By this method, $53 \mu \mathrm{g}$. of gadolinium was separated from the solutious containing $1 \mathrm{mg}$. each aluminum and $1 \mathrm{ron}($ III). The recovery of gadoilinium was 98 to $99 \%$.

At $\mathrm{pH} 4.5$ the following ions will be extracted into 8-quinolinol-chloroform: aluminum, copper, iron(III), gallium, indium, molybdenum(VI), niobium, nickel, tin(IV), titanium, thallium(III), and vanadium. $13,14,15$ Cobalt, manganese, and lead will not be extracted.

TTA extraction at $\mathrm{pH}$ 1.3. Feldman and Ellenburg ${ }^{16}$ separated a small amount (not specified) of thorium from rare earths by extraction with TTA in xylene at $\mathrm{pH} 1.0$ and at $60^{\circ} \mathrm{C}$. The following experiments were conducted in order to know if complete removal of thorium would be achieved at room temperature $\left(\sim 25^{\circ} \mathrm{C}.\right)$.

Aqueous phase: about $15 \mathrm{mi} ., \mathrm{pH} 1.3(0.05 \mathrm{M}$ in nitric acid). 
Three extractions ( 5 minutes each) with 10-ml. portions of $0.5 \underline{M}$ TTA in xylene.

The aqueous phase was washed with $10 \mathrm{ml}$. of $x y l e n e$ and evaporated to dryness. After destruction of organic matter with nitric and perchloric acids, gadolinium was determined with arsenazo.

As shown in Table II, gadolinium can be separated from 10 $\mathrm{mg}$. of thorium. For less than $1 \mathrm{mg}$. of thorium, two extractions are sufficient. The TTA extraction at $\mathrm{pH} 1.3$ also removes copper, scandium, and zirconium. Extractions of iron(III) and uranium(VI) are very incomplete.

TABLE II. DETERMINATION OF GADOLINIUM AFTER TTA EXTRACTION AT $\mathrm{pH} 1.3$

\begin{tabular}{|c|c|c|c|}
\hline Addition & $\begin{array}{c}\text { Gd Taken, } \\
\\
\mu \mathrm{g}\end{array}$ & $\begin{array}{l}\text { Gd Found, } \\
\mu \mathrm{g}\end{array}$ & $\begin{array}{c}\text { Average } \\
\text { Recovery, \$ }\end{array}$ \\
\hline- & - & $0.7,0.7$ & - \\
\hline- & 53.0 & $49 \cdot 5,50.0$ & 94.0 \\
\hline $1.0 \mathrm{mg} \cdot \mathrm{Cu}$ & - & $0.0^{b}, 0.0^{b}$ & - \\
\hline $1.0 \mathrm{mg} \cdot \mathrm{Cu}$ & 53.0 & $50 \cdot 0^{b}, 50 \cdot 0^{b}$ & 94.3 \\
\hline $0.10 \mathrm{mg} \cdot \mathrm{Fe}(\mathrm{III})$ & - & $17 \cdot 0,10 \cdot 5$ & - \\
\hline $0.0125 \mathrm{mg} \cdot \mathrm{Fe}$ (III) & - & $1.0,1.0$ & - \\
\hline $0.0125 \mathrm{mg} \cdot \mathrm{Fe}(\mathrm{III})$ & 53.0 & $48 \cdot 5,48 \cdot 5$ & 91.5 \\
\hline $0.10 \mathrm{mg} \cdot \mathrm{Sc}$ & - & $0.7,1.0$ & - \\
\hline $0.10 \mathrm{mg} \cdot \mathrm{sc}$ & 53.0 & $48.0,48.5$ & 91.1 \\
\hline $10 \mathrm{mg} \cdot \mathrm{Th}$ & - & $1 \cdot 5,1 \cdot 5$ & - \\
\hline $10 \mathrm{mg} . \mathrm{Th}$ & 53.0 & $50 \cdot 0,50 \cdot 5$ & 94.9 \\
\hline
\end{tabular}




\section{TAELE II (Concluded)}

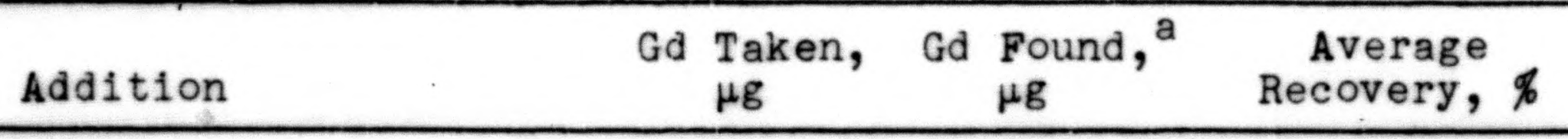

$20 \mathrm{mg}$. Th

- $4.5,5.5$

$20 \mathrm{lng}$. Th

53.0

$49.0,50.0$

93.4

$5 \mathrm{mg}$. Th, 0.014 mmole $\mathrm{Na}_{2} \mathrm{SO}_{4}$

- $0.0,0.0$

$5 \mathrm{mg}$. Th, 0.014 mmole $\mathrm{Na}_{2} \mathrm{SO}_{4}$

53.0

$50.0,50.0$

94.3

$0.20 \mathrm{mg}$. U(VI)

- $\quad 22.5,24.0$

$0.10 \mathrm{mg}$. U(VI)

53.0

$48.0,49.0$

91.5

$1.0 \mathrm{mg} . \mathrm{Zr}$

- $0.0,0.0$

$1.0 \mathrm{mg} . \mathrm{zr}$

53.0

$49.5,49.0$

93.0
a Values obtained with $53 \mu \mathrm{g}$. Gd were corrected for respective bianks.
b Two TTA extractions.

TTA extraction at $\mathrm{pH}$ 4.5. After removal of thorium, Feldman and Ellenburg ${ }^{16}$ extracted rare earths with TTA in xylene at $\mathrm{pH} 4.5$ and at $60^{\circ} \mathrm{C}$. and determined them spectrographically. Menis et al. ${ }^{17}$ extracted lanthanum into TTA in 4-methyl-2pentanorie and determined it by a flame photometer. In the present work, the extraction of gadolinium at room temperature was studied under the following conditions:

Aqueous phase: about $10 \mathrm{mi} ., \mathrm{pH} 4.5$ ( $0.1 \mathrm{M}$ in acetate).

Two extractions ( 5 minutes each) with 10-ml. portions of 0.5 M TTA in xylene. The combined organic phase was washed with $10 \mathrm{ml}$. of $\mathrm{pH} 4.5$ solution ( $0.1 \mathrm{M}$ in acetate). 
Back-extraction ( 5 minutes) of gadolinium with $15 \mathrm{ml}$. of 1 M nitric acid. The back-extract was washed with $10 \mathrm{ml}$. of xylene.

The aqueous phase was evaporated to dryness. After destruction of organic matter, gadolinium was determined with a r senazo.

The results are shown in Table III.

TABLE III. DETERMINATION OF GADOLINIUM AFTER TTA EXTRACTION AT $\mathrm{pH} 4.5$.

\begin{tabular}{cccc}
\hline Addition & $\begin{array}{c}\text { Gd Taken, } \\
\mu \mathrm{g}\end{array}$ & $\begin{array}{c}\text { Gd Found, } \\
\mu \mathrm{g}\end{array}$ & $\begin{array}{c}\text { Average } \\
\text { Recovery, \% }\end{array}$ \\
\hline- & 15.9 & $14.5,14.5$ & 91.2 \\
- & 53.0 & $50.0,50.0$ & 94.1 \\
- & 79.5 & $75.0,75.0$ & 94.3 \\
$1.0 \mathrm{mmole} \mathrm{Na}_{2} \mathrm{SO}_{4}$ & 53.0 & $49.0,50.0$ & 93.4 \\
$10 \mathrm{mg} \cdot \mathrm{Mg}$ & 53.0 & $48.5,49.5$ & 92.4 \\
$10 \mathrm{mg} \cdot \mathrm{Ca}$ & 53.0 & $51.0,50.5$ & 95.8 \\
$1.0 \mathrm{mg} \cdot \mathrm{Ca} \cdot \mathrm{Cd}$ & 53.0 & $50.5,51.0$ & 95.8 \\
\hline
\end{tabular}

a Corrected for blanks which were in the range $1.0-2.5 \mu \mathrm{g}$. Gd.

Back-extraction of gadolinium with $2 \underline{\mathrm{M}}$ nitric acid gave the same recovery, 1.e., $94.9 \%$ with $53 \mu \mathrm{g}$. Gd. Double back-extractions with $15 \mathrm{ml}$. and $10 \mathrm{ml}$. of $1 \mathrm{M}$ nitric acid did not improve the recovery, 1.e., $95.3 \%$ with $53 \mu \mathrm{g}$. Gd. Positive interferences were observed with $1.0 \mathrm{mg} . \mathrm{Ag}$, $1.0 \mathrm{mg}$. Mo(VI), $1.0 \mathrm{mg} . \mathrm{Pb}$, and $0.1 \mathrm{mg}$. $\mathrm{Zn}$. It may be concluded 
that the TTA extraction at $\mathrm{pH} 4.5$ is sultable only for the separation of rare earths from magnesium, calcium, and probably strontium and barium.

By carrying out three TTA extractions at $\mathrm{pH} 1.3$ and two TTA extractions at $\mathrm{pH} 4.5,53 \mu \mathrm{g}$. of gadolinium was separated from $10 \mathrm{mg}$. each thorium and calcium. The recovery of gadolinium was 91\%.

Procedure in the absence of thorium. When thorium and zirconium are absent in the sample, the TTA extraction at $\mathrm{pH}$ 1.3 can be omitted. If the sample contains microgram amounts of thorium, the method described previousiy by onishi et al. ${ }^{10}$ can be applied. The procedure that consists of fluoride precipitation, 8-quinolinol-chloroform extraction at pH 4.5-4.8, and TTA-xylene extraction at the same pH provides for the presence of many elements (Table IV). The separation of milligram amounts of lead and uranium from rare earths is not satisfactory. Lead was precipitated almost completely as fluoride, and further purification steps did not remove lead. Methods for the separation of rare earths from uranium ${ }^{5,6}$ have previously been published. 
TABLE IV. SEPARATION OF GADOLINIUM FROM OTHER ELEMENTS

(TTA extraction at $\mathrm{pH} 1.3$ omitted)

\begin{tabular}{|c|c|c|c|}
\hline Addition & $\begin{array}{c}\text { Gd Taken, } \\
\mu \mathrm{g}\end{array}$ & Gd Found, ${ }_{\mu \mathrm{g}}^{\mathrm{a}}$ & $\begin{array}{c}\text { Average } \\
\text { Reccvery, }\end{array}$ \\
\hline- & - & $1 \cdot 5,1 \cdot 7$ & - \\
\hline - & 53.0 & $50 \cdot 5,50 \cdot 5$ & 95.3 \\
\hline $20 \mathrm{mg} \cdot \mathrm{Al}$ & - & $0.7,0.1+$ & - \\
\hline $20 \mathrm{mg} \cdot \mathrm{Al}$ & 53.0 & $49.5,50.0$ & 94.0 \\
\hline $1.0 \mathrm{mg} \cdot \mathrm{Co}(\mathrm{II})$ & - & c.7, 0.4 & - \\
\hline $1.0 \mathrm{mg} \cdot \mathrm{Co}$ (II) & $53 . c$ & $50 \cdot 5,50 \cdot 0$ & 94.9 \\
\hline $1.0 \mathrm{mg} \cdot \mathrm{Cr}($ III $)$ & - & $0.0,0.0$ & - \\
\hline $1.0 \mathrm{mg} \cdot \operatorname{Cr}(\mathrm{III})$ & 53.0 & $50.0,50.0$ & $94 \cdot 3$ \\
\hline $51 \mathrm{mg} \cdot \mathrm{Cu}\left(\right.$ as $\mathrm{CuSO}_{4}$ ) & - & $1.0,0.7$ & - \\
\hline $51 \mathrm{mg} \cdot \mathrm{Cu}$ (as $\mathrm{CuSO}_{4}$ ) & 53.0 & $50 \cdot 0,50 \cdot 5$ & 94.9 \\
\hline $42 \mathrm{mg} \cdot \mathrm{Fe}($ III $)$ & - & $0.6,1.3$ & - \\
\hline 42 mg. $F e(I I I)$ & 53.0 & $50.0,49.0$ & 93.4 \\
\hline $84 \mathrm{mg} \cdot \mathrm{Fe}(\mathrm{III})$ & - & $0.4,1.3$ & - \\
\hline $84 \mathrm{mg} \cdot \mathrm{Fe}(\mathrm{III})$ & 53.0 & $50.0,49.5$ & 94.0 \\
\hline $10 \mathrm{mg} \cdot \mathrm{Mn}(\mathrm{II})$ & - & $7 \cdot 0,7 \cdot 5$ & - \\
\hline $10 \mathrm{mg} \cdot \mathrm{Mn}(\mathrm{II})$ & 53.0 & $49.5,48.2$ & 92.2 \\
\hline $1.0 \mathrm{mg} \cdot \mathrm{Mn}(\mathrm{II})$ & - & $2 \cdot 0,2 \cdot 5$ & - \\
\hline $1.0 \mathrm{mg} \cdot \mathrm{Mn}(\mathrm{II})$ & 53.0 & $51.0,51.0$ & 96.2 \\
\hline $20 \mathrm{mg}$. Mo (as ammonium molybdate) & - & $1.6,1.4$ & - \\
\hline $20 \mathrm{mg}$. Mo (as ammonium molybdate) & 53.0 & $50 \cdot 5,50 \cdot 0$ & $94 \cdot 9$ \\
\hline $20 \mathrm{mg} \cdot \mathrm{Nb}$ & - & $0.0,0.0$ & - \\
\hline $20 \mathrm{mg} \cdot \mathrm{Nb}$ & 53.0 & $50.0,49.0$ & 93.4 \\
\hline
\end{tabular}


TABLE IV (Concluded)

\section{Addition}

$15 \mathrm{mg}$. N1

$15 \mathrm{mg}$. N1

10 mg. $\mathrm{P}$ (as $\mathrm{KH}_{2} \mathrm{PO}_{4}$ )

$10 \mathrm{mg}$. P (as $\mathrm{KH}_{2} \mathrm{PO}_{4}$ )

$5.0 \mathrm{mg} . \mathrm{Pb}$

$0.10 \mathrm{mg} \cdot \mathrm{Pb}$

$0.10 \mathrm{mg} . \mathrm{Pb}$

20 mg. T1

20 mg. T1

$10 \mathrm{mg}$. U(VI)

$0.20 \mathrm{mg}$. U(VI)

$0.20 \mathrm{mg}$. U(VI)

$5.0 \mathrm{mg} \cdot \mathrm{V}(\mathrm{V})$

$5.0 \mathrm{mg} . \mathrm{V}(\mathrm{V})$

$10 \mathrm{mg}$. W(VI)

$10 \mathrm{mg}$. W(VI)

$2.0 \mathrm{mg} . \mathrm{Zn}$

$2.0 \mathrm{mg} . \mathrm{Zn}$
Gd Taken, Gd Found, ${ }^{a}$ Average $\mu \mathrm{g}$ $\mu \mathrm{g}$ Recovery, \%

$$
0.6,0.3
$$

$53.0 \quad 50.0,50.5$

94.9

- $\quad 0.0,0.0$

$53.0 \quad 50.5,51.0$

95.8

- 110,110

- $\quad 2.4,2.1$

$53.0 \quad 50.0,49.0 \quad 93.4$

$-\quad 0.2,0.6$

$53.0 \quad 51.0,49.5 \quad 94.9$

$-\quad 31.5,31.5$

$-\quad 2.5,2.0$

$53.0 \quad 51.0,51.0 \quad 96.2$

- $\quad 0.9,0.0$

$53.0 \quad 50.5,50.0 \quad 94.9$

- $\quad 1.9,1.4$

$53.0 \quad 50.0,49.5 \quad 94.0$

$-\quad 2.2,1.9$

$53.0 \quad 50.5,50.5 \quad 95.3$

Values obtained with 53 Hg. Gd were corrected for respective blanks.

General procedure. Results obtained in applying the proposed procedure are collected in Table V. 
TABLE V. SEPARATION OF RARE EARTHS FROM OTHER ELEMENTS - GENERAL PROCEDURE

\begin{tabular}{|c|c|c|c|c|}
\hline Addition & $\begin{array}{r}\text { Rare } \\
\text { Earth }\end{array}$ & Taken & $\underset{\text { Found }}{\mu \mathrm{g}}$ & $\begin{array}{c}\text { Average } \\
\text { Recovery, }\end{array}$ \\
\hline - & - & - & $0.0-0.6^{b}$ & - \\
\hline - & Gd & 21.2 & $20.0,19.0$ & 92.0 \\
\hline - & Gd & 53.0 & $48.0,48.0$ & 90.6 \\
\hline - & Gd & 79.5 & $71 \cdot 0,71 \cdot 5$ & 89.7 \\
\hline - & $\mathrm{Ce}$ & 58.0 & $51 \cdot 5,52 \cdot 0$ & 89.7 \\
\hline - & $\mathrm{Y}$ & 39.0 & $35.2,35.2$ & 90.2 \\
\hline $10 \mathrm{mg} \cdot \mathrm{Th}$ & - & - & $1.1^{\mathrm{c}}, 1.1^{\mathrm{c}}$ & - \\
\hline i0 mg. Th & Gd & 53.0 & $40.0^{c}, 39.5^{c}$ & 75.1 \\
\hline $10 \mathrm{mg} \cdot \mathrm{Th}$ & - & - & $1.9^{\mathrm{d}}, 1.7^{\mathrm{d}}$ & - \\
\hline $10 \mathrm{mg} . \mathrm{Th}$ & Gd & 53.0 & $46.0^{\mathrm{d}}, 45.0^{\mathrm{d}}$ & 86.8 \\
\hline $1.0 \mathrm{mg} \cdot \mathrm{Sc}$ & - & - & $2.4,2.4$ & - \\
\hline $1.0 \mathrm{mg} \cdot \mathrm{Sc}$ & Gd & 53.0 & $46.5,47.0$ & 88.3 \\
\hline $0.10 \mathrm{mg} \cdot \mathrm{Zr}$ & - & - & $0.0,0.3$ & - \\
\hline $0.10 \mathrm{mg} \cdot \mathrm{Zr}$ & Gd & 53.0 & $47 \cdot 0,47 \cdot 0$ & 88.6 \\
\hline $1.0 \mathrm{mg} . \mathrm{Th}$ & - & - & $0.6,0.4$ & - \\
\hline $1.0 \mathrm{mg} . \mathrm{Th}$ & Gd & 53.0 & $48.0,48 \cdot 5$ & 91.1 \\
\hline $42 \mathrm{mg}$. Fe(III), $1.0 \mathrm{mg}$. Th & - & - & $0.9,0.9$ & - \\
\hline $42 \mathrm{mg} \cdot \mathrm{Fe}($ III $), 1.0 \mathrm{mg}$. Th & Gd & 53.0 & $47 \cdot 0,47 \cdot 5$ & 89.2 \\
\hline
\end{tabular}

Values obtained with rare earths were corrected for respective blanks.

b Av. of 10 experiments $=0.2 \mu \mathrm{g}$.

c Fiuoride precipitation without Ca; three TTA extractions at pH 1.3 .

d Three TTA extractions at $\mathrm{pH} 1.3$. 
In the presence of $1 \mathrm{mg}$. $\mathrm{Zr}$, emulsion was formed during the TTA extraction at $\mathrm{pH}$ 1.3. It was found that the evaporation of perchloric acid solution of calcium and zirconium to dryness caused this emulsion formation. From Table V it is seen that $10 \mathrm{mg}$. Th is not so effective as $10 \mathrm{mg}$. Ca as a carrier for gadolinium.

The average recovery of the last 4 experiments in Table V is $89.3 \%$ (coefficient of variation $=1.4 \%$ ). This value is very close to the average of $90.4 \%$ for the first 5 experiments in the same table (coefficient of variation $=0.9 \%$ ), and the construction of the calibration curve through the entire procedure is justified. It may be mentioned that the method of Bornong and Moriarty ${ }^{7}$ for the determination of rare earths in cast steels gave an average recovery of $89 \%$, with a coefficient of variation of $7 \%$.

Acknowledgment - The authors wish to thank Dr. E. B. Sandell of the University. of Minnesota for suggesting the use of the 8-quinolinol extraction.

\section{REFERENCES}

1. J.Herringtor and K. C. Steed, Anal. Chim. Acta, 1960, 22, 180 .

2. F. V. ZaYkovski1 and G. F. Sadova, Zhur. Anal. Khim., 1961, 16,29 .

3. S. B. Savvin, Talanta, $1961,8,673$.

4. J. P. Young, J. C. White, and R. G. Ball, Anal. Chem., 1960, 32, 928.

5. J.S. Fritz, M. J. Richard, and W. J. Lane, Anal. Chem., $1958,20,1776$. 

6. C. V. Banks, J.A. Thompson, and J. W. O'Laughlin,
Anal. Chem., 1958, 30, 1792.

7. B. J. Bornong and J. L. Moriarty, Anal. Chem., 1962, 34, 871.

8. F. V. ZaYkovskiY and V. S. Baschmakova, Zhur. Anal. Khim.,

9. F. A. Fer'yanchich, Trudy Tsentral. Nauch. -Issledovatel. Gornorazved. Inst., $1260, \frac{10604 .}{50.39,72 ; \text { Chem. }}$.

10. H. Onishi, H. Nagai, and Y. Toita, Anal. Chim. Acta, 1962,
26,528 .

11. V. I. Kuznetsov, Zhur. Anal. Khtm., 1952, 2, 226.

12. S. Shibata, F. Takeuchi, and T. Matsumae, Bull. Chem. Soc. Japan, 1958, 31, 888.

13. E. B. Sandell, Colorimetric Determination of Traces of Metals. Interscience Publishers, New York, 3rd Ed., 1959.

14. G. H. Morrison and H. Freiser, Solvent Extraction in Analytical Chemistry. Wiley, New York, 1957.

15. K. Motojima and H. Hashitani, Bunseki Kagaku, 1960, 2, 151 .

16. C. Feldman and J. Y. Ellenburg, Anal. Chem., 1958, 30, 418.

17. Meris, T. C. Rains, and J. A. Dean, Anal. Chem., 1959,

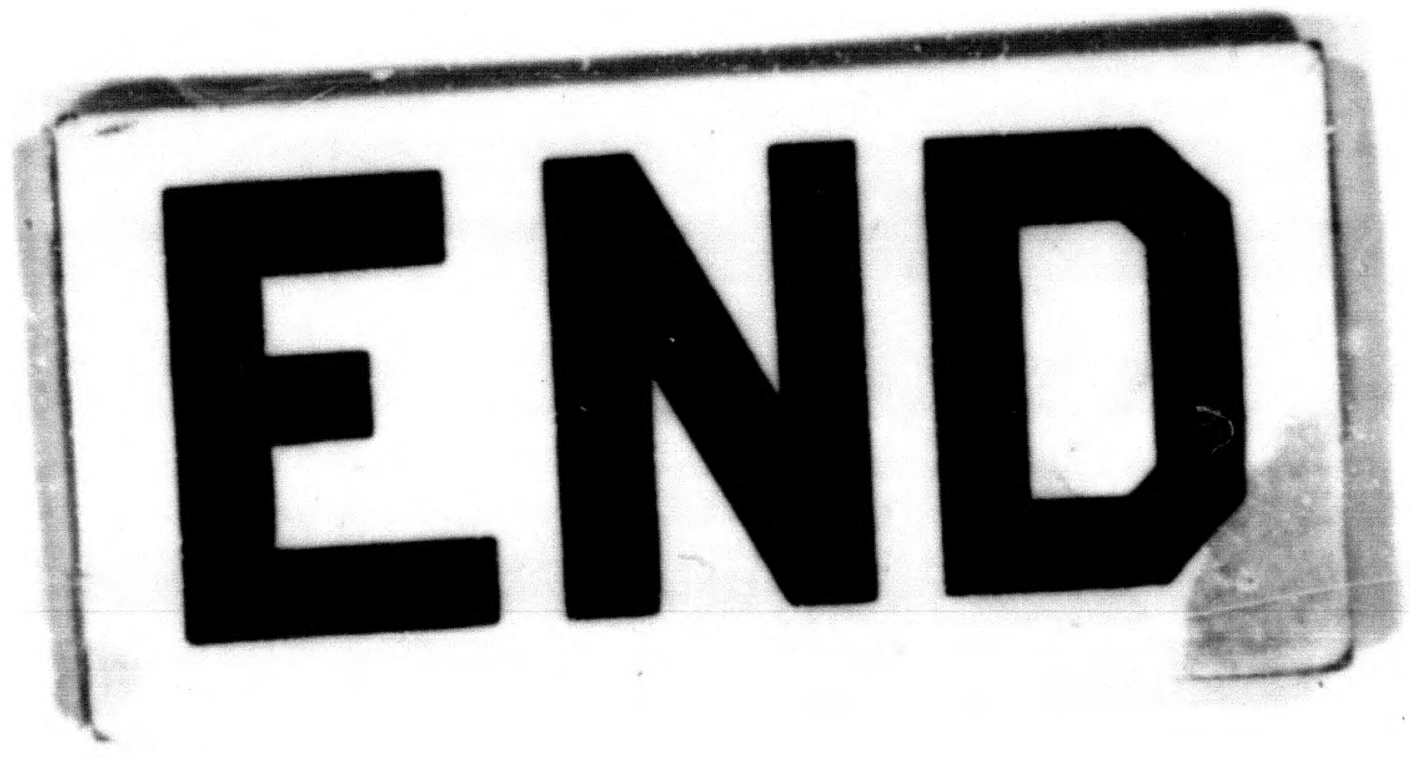

